\title{
INTELLECTUAL CAPITAL : SALAH SATU PENENTU KEUNGGULAN BERSAING
}

\author{
Indra Lila Kusuma \\ STIE AAS Surakarta \\ Email : i_lilakusuma@yahoo.com
}

\begin{abstract}
ABSTRAK
Tulisan ini menguraikan tentang bagaimana modal intelektual atau intellectual capital sangat berperan dam mengantarkan perusahaan memenangkan persaingan atau keunggulan bersaing (competitive advantage). Selama ini faktor faktor produksi seperti tenaga kerja, uang, bangunan , tanah dan lainnya dianggap sebagai penentu keunggulan yg bisa membuat suatu perusahaan memenangkan persaingan, faktor produksi lebih ditekankan pada jumlah yang dimiliki, karena itu semua adalah asset yang sangat berharga dalam menjamin keberlangsungan hidup suatu perusahaan. Namun tidak bisa dipungkiri, perubahan yang sangat cepat mengakibatkan persaingan juga semakin ketat, yang mengharuskan perusahaan untuk terus berinovasi dalam menghasilkan produk-produk yang semakin modern guna memenuhi permintaan pasar yang semakin modern. Untuk dapat bersaing suatu perusahaan dituntuk untuk terus melakukan inovasi baik pada produk maupun teknologi yang digunakan, karena inovasi merupakan salah satu dari kunci sukses suatu usaha yaitu cost, quality, innovation and time. Untuk melakukan semua itu, perusahaan tidak bisa lagi hanya mengandalkan faktor -faktor produksi yang dimilikinya selama ini, tapi lebih dari itu, yaitu suatu modal yang disebut intellectual capital.
\end{abstract}

\section{PENDAHULUAN}

Di masa lalu, kekayaan dan daya saing suatu negara senantiasa dikaitkan dengan kepemilikan sumberdaya yang bersifat fisik. Sumberdaya fisik tersebut tercermin di dalam berbagai faktor produksi seperti tenaga kerja, uang, bangunan, tanah dan lainnya. Sedangkan kebutuhan terhadap pengetahuan kurang mendapat perhatian. Kebutuhan akan pengetahuan di masa lalu hanya sebatas aktivitas yang terkait dengan faktor produksi.
Namun persaingan yang semakin ketat sekarang ini, memaksa siapapun yang ingin memdapatkan keunggulan bersaing (competitive advantage) untuk mengubah cara mereka berfikir. Kekayaan ataupun faktor produksi yang berlimpah belum bisa menjamin suatu perusahaan bisa memenangkan persaingan. Sehubungan dengan pencapaian competitive advantage maka perusahaanperusahaan mulai mengubah bisnis mereka menuju bisnis berdasarkan pengetahuan, 
dengan karakteristik utama ilmu pengetahuan (Tjiptohadi \& Agustine, 2003). Hal tersebut dilakukan dengan cara mengoptimalkan factor-faktor kunci sukses ( cost, quality, innovation, dan time).

Perusahaan yang bisa unggul adalah perusahaan yang mempunyai kekuatan yang benar-benar unik dan sulit ditiru oleh para pesaingnya, dan itu bisa dilihat dari adanya adaptasi, inovasi dan kualitas sumberdaya manusia dalam mengantisipasi perubahan yang begitu cepat. Keunggulan seperti ini hanya bisa dicapai apabila perusahaan tersebut mempunyai basis sumber daya. Dalam hal ini Pitts at al (2003) membagi sumber daya perusahaan dalam tiga jenis yaitu sumber daya nyata, sumber daya tidak nyata dan sumber daya manusia.. Sumber daya nyata sangat mudah diidentifikasi dan dievaluasi seperti kemampuan keuangan dan aset-aset yang tercermin dalam neraca perusahaan. Hanya dengan melihat kemampuan keuangan dan aset-aset yang dimilki, keunggulan suatu perusahaan sudah bisa diketahui dengan membandingkannya dengan perusahaan pesaing. Namun dengan menggunakan ilmu pengetahuan dan teknologi maka akan dapat diperoleh bagaimana cara menggunakan sumber daya lainnya secara efisien dan ekonomis, yang nantinya akan memberikan keunggulan bersaing .Hal tersebut juga didukung oleh pandangan Choo (1998), yang menyatakan bahwa perusahaan yang benarbenar mampu bertahan lama, terus berkembang, bukan karena ukuran dan keberuntungan, tetapi karena memang perusahaan-perusahaan tersebut mampu menunjukkan kapasitasnya untuk beradaptasi lebih cepat dengan tuntutan zaman. Perusahaan tersebut secara terus menerus melakukan inovasi, dan mengambil tindakan yang tepat untuk menggerakkan perusahaannya ke arah tujuan yang diinginkan, kemampuan tersebut hanya mungkin terwujud jika perusahaan tersebut secara efektif menggunakan sumber daya pengetahuan atau intellectual capital.

Di Indonesia fenomena Intellectual Capital mulai berkembang terutama setelah munculnya PSAK No. 19 (revisi 2000) tentang aktiva tidak berwujud. Menurut PSAK No. 19 (revisi 2000), aktiva tidak berwujud adalah aktiva non-moneter yang dapat diidentifikasi dan tidak mempunyai wujud fisik serta dimiliki untuk digunakan dalam menghasilkan atau menyerahkan barang atau jasa, disewakan kepada pihak lainnya, atau untuk tujuan administratif (IAI, 2002). Paragraph 09 dari PSAK No. 19 (revisi 2000) menyebutkan beberapa contoh dari aktiva tidak berwujud antara lain ilmu pengetahuan dan teknologi, desain dan implementasi sistem atau proses baru, lisensi, hak kekayaan intelektual, pengetahuan mengenai pasar dan merek dagang (termasuk merek produk). Selain itu juga ditambahkan piranti lunak komputer, hak paten, hak cipta, film gambar hidup, daftar pelanggan, hak pengusahaan hutan, kuota impor, waralaba, hubungan dengan pemasok atau pelanggan, kesetiaan pelanggan, hak pemasaran, dan pangsa pasar. 


\section{PEMBAHASAN}

Intellectual capital memiliki peran yang sangat penting dan stategis di perusahaan dalam mengukur sumber daya manusia didalamnya. Dalam akuntansi intellectual capital dikategorikan dalam asset tidak berwujud. Intellectual capital merupakan intangible asset yang sangat penting di era informasi dan pengetahuan, dimana intellectual capital mengacu kepada pengetahuan dan kemampuan yang dimiliki oleh suatu kolektivitas social, seperti organisasi, komunitas intellectual atau professional . Intellectual capital merupakan pengetahuan yang bisa memberikan manfaat bagi perusahaan., manfaat tersebut berarti pengetahuan ini mampu menyumbangkan sesuatu atau memberikan kontribusi yang dapat memberikan nilai tambah dan kegunaan berbeda bagi perusahaan, berbeda berarti pengetahuan tersebut merupakan salah satu identifikasi yang membedakan suatu perusahaan dengan perusahaan lain Santosa dan Setiawan (2008).

\section{Pengertian Intellectual Capital}

Tidaklah mudah untuk dapat menyajikan definisi yang tepat tentang intellectual capital. Definisi intellectual capital yang ditemukan dalam beberapa literatur cukup kompleks dan beragam. Salah satu definisi intellectual capital yang banyak digunakan adalah yang ditawarkan oleh Organisation for Economic Co-operation and Development (OECD, 1999) yang menjelaskan IC sebagai nilai ekonomi dari dua kategori aset tak berwujud: (1) organisational (structural) capital; dan (2) human capital.

Klein dan Prusak juga menyatakan apa yang kemudian menjadi standar pendefinisian $I C$, dan dipopularisasikan oleh Steward (1994). Menurut Klein dan Prusak "...we can define intellectual capital operationally as intellectual material that has been formalized, captured, and leveraged to produce a higher valued asset" (Steward 1994).

The Society of Management Accountants of Canada (SMAC) mendefinisikan intellectual assets sebagai berikut: In balance sheet, intellectual assets are those knowledge-based items, which the company owns which will produced a future stream of benefits for the company (International Federation of Accountants ( IFAC), 1998).

Banyak praktisi yang menyatakan bahwa IC terdiri dari tiga elemen utama (Sveiby, 2001; Bontis, 2001; Steward 2002; Boekestein, 2006) yaitu:

1. Human Capital (modal manusia)

Human capital merupakan lifeblood dalam IC. Disinilah sumber innovation dan improvement, tetapi merupakan komponen yang sulit untuk diukur. Human capital juga merupakan tempat bersumbernya pengetahuan yang sangat berguna, keterampilan, dan kompetensi dalam suatu organisasi atau perusahaan. Human capital mencerminkan kemampuan kolektif perusahaan untuk menghasilkan solusi terbaik berdasarkan pengetahuan yang dimiliki orang-orang yang ada dalam 
perusahaan tersebut. Human capital akan meningkat jika perusahaan mampu menggunakan pengetahuan yang dimiliki oleh karyawannya. (Brinker 2002) memberikan beberapa karakteristik dasar yang dapat diukur dari modal ini, yaitu training programs, credential, experience, competence, recruitment, mentoring, learning program, individual potential and personality

2. Structural Capital atau Organizational Capital (modal organisasi)

Structural capital merupakan kemampuan organisasi atau perusahaan dalam memenuhi proses rutinitas perusahaan dan strukturnya yang mendukung usaha karyawan untuk menghasilkan kinerja intelektual yang optimal serta kinerja bisnis secara keseluruhan, misalnya: sistem operasional perusahaan, proses manufacturing, budaya organisasi, filosofi manajemen dan semua bentuk intellectual property yang dimiliki perusahaan. Seorang individu dapat memiliki tingkat intelektualitas yang tinggi, tetapi jika organisasi memiliki sistem dan prosedur yang buruk maka $I C$ tidak dapat mencapai kinerja secara optimal dan potensi yang ada tidak dapat dimanfaatkan secara maksimal.

3. Relational Capital atau Customer Capital (modal pelanggan)

Elemen ini merupakan komponen modal intelektual yang memberikan nilai secara nyata. Relational capital merupakan hubungan yang harmonis/ association network yang dimiliki oleh perusahaan dengan para mitranya, baik yang berasal dari para pemasok yang andal dan berkualitas, berasal dari pelanggan yang loyal dan merasa puas akan pelayan perusahaan yang bersangkutan, berasal dari hubungan perusahaan dengan pemerintah maupun dengan masyarakat sekitar. Relational capital dapat muncul dari berbagai bagian diluar lingkungan perusahaan yang dapat menambah nilai bagi perusahaan tersebut. Dengan kata lain Customer Capital adalah pengetahuan yang melekat dalam marketing channels dan customer relationship yang dikembangkan oleh suatu organisasi.

Sebenarnya masih banyak definisi dari intellectual capital menurut pakar dan kalangan bisnis, namun secara umum jika diambil suatu benang merah dari berbagai definisi intellectual capital yang ada, maka intellectual capital dapat didefinisikan sebagai jumlah dari apa yang dihasilkan oleh tiga elemen utama organisasi (human capital, structural capital, costumer capital yang berkaitan dengan pengetahuan dan teknologi yang dapat memberikan nilai lebih bagi suatu organisasi berupa keunggulan bersaing .

\section{Klasifikasi Intellectual Capital}

Lebih lanjut, berikut adalah klasifikasi intellectual capital berdasarkan masingmasing kategori: 


\section{Klasifikasi \\ Intellectual Capital}

\begin{tabular}{|c|c|c|}
\hline Organizational Capital & Relational Capital & Human Capital \\
\hline $\begin{array}{l}\text { Intellectual Property: } \\
\text { - } \quad \text { Paten } \\
\text { - } \quad \text { Copy rights } \\
\text { - } \quad \text { Design rights } \\
\text { - } \quad \text { Trade secret } \\
\text { - } \quad \text { Trademarks } \\
\text { - } \quad \text { Service marks } \\
\text { Infrastructure Assets: } \\
\text { - } \quad \text { Filosofi manajemen } \\
\text { - } \quad \text { Budaya perusahaan } \\
\text { - } \quad \text { Sistem informasi } \\
\text { - } \quad \text { Sistem jaringan } \\
\text { - } \quad \text { Hubungan keuangan }\end{array}$ & $\begin{array}{ll}\text { - } & \text { Brand } \\
\text { - } & \text { Konsumen } \\
\text { - } & \text { Loyalitas konsumen } \\
\text { - } & \text { Nama perusahaan } \\
\text { - } & \text { Backlog orders } \\
\text { - } & \text { Jaringan distribusi } \\
\text { - } & \text { Kolaborasi bisnis } \\
\text { - } & \text { Kesepakatan lisensi } \\
\text { - } & \text { Kontrak-kontrak } \\
\text { - } & \text { Kesepakatan franchise }\end{array}$ & $\begin{array}{ll}\text { - } & \text { Know-how } \\
\text { - } & \text { Pendidikan } \\
\text { - } & \text { Vocational qualification } \\
\text { - } & \text { Pekerjaan dihubungkan } \\
\text { dengan pengetahuan } \\
\text { - } \\
\text { - } \\
\text { - } \quad \text { Senilaian psychometric } \\
\text { inovatif, proaktif, reaktif dan } \\
\text { kemampuan untuk berubah }\end{array}$ \\
\hline
\end{tabular}

Sumber: IFAC, 1998

\section{Contoh Kasus}

Berikut adalah contoh kegagalan perusahaan yang belum mengedepankan intellectual capital dalam menjalankan perusahaannya. Kasus yang sering disebut The death of Samurai, Robohnya perusahaan-perusahaan raksasa Jepang seperti Sony, Panasonic, Sharp, Toshiba dan Sanyo, langit diatas Tokyo terasa begitu kelabu, ada kegetiran yang mencekam dibalik gedung-gedung raksasa yang menjulang disana. Industri elektronika Jepang yang begitu kuat dan berkuasa 20 tahun silam sekarang perlahan memasuki lorong keruntuhan. Dimulai dengan Sony yang kemudian diikuti Panasonic dan Sharp mengumumkan angka kerugiannya trilyunan rupiah. Harga-harga saham perusahaan raksasa tersebut menurun tajam. Sanyo bahkan harus rela menjual dirinya dikarenakan sudah hampir bangkrut. Sementara itu Sharp berencana menutup divisi Air Conditioner (AC) dan TV Aquosnya. Selanjutnya Sony dan Panasonic akan memberhentikan ribuan karyawan. Dan yang terakhir Toshiba sebentar kemungkinan akan mengalami kebangkrutan di divisi notebooknya, setelah produk televisinya juga mati. kegagalan demi kegagalan terus menghujam industri elektronika raksasa Jepang. Dan beberapa penyebabnya adalah adanya serbuan Samsung dan LG yang sangat menghentakkan perusahaan-perusahaan elektronika Jepang. Bagi perusahaan elektronika Jepang, kedua Produk Korea sangat mengancam posisi produk mereka di pasar. Disisi lain, produk-produk elektronika dari Cina dan produk domestic dengan harga yang amat murah juga terus mengerus pasar produk Jepang, sementara itu dalam kategori digital gadgets, Apple telah membuat Sony tidak bergerak. Lalu apakah yang 
menyebabkan perusahaan -perusahaan elektronika Jepang bisa seperti itu? Ada 3 faktor fundamental yang menyebabkannya yaitu:

1. Harmony Culture Error, dalam era digital seperti saat ini, kecepatan adalah kunci, speed in decision making. Speed in product development, speed in product launch dan dalam hal ini perusahaan Jepang kini tertinggaldikarenakan budaya mereka yang sangat mengagungkan harmoni dan consensus. Budaya kerja yang sangat menjunjung consensus bisa dilihat salah satunya seperti Top manajemen perusahaan -perusahaan Jepang bias menghabiskan waktu berminggu-minggu hanya sekedar untuk menemukan consensus mengenai produk apa yang akan diluncurkan. Tapi sayangnya pada saat rapat selesai, Samsung dan LG sudah keluar dengan produk baru. Budaya yang mementingkan consensus membuat perusahaan-perusahaan Jepang sangat lamban dalam membuat keputusan dan ini artinya kegagalan. Budaya yang menjaga harmoni juga membuat ide-ide kreatif yang radical nyaris tidak pernah bisa berkembang.

2. Seniority error, dalam era digital, inovasi adalah oksigen, inovasi adalah nafas yang tetap mempertahankan keberlangsungan perusahaan, sayangnya budaya inovasi ini tidak kompatibel dengan budaya kerja yang mementingkan seniority . Hampir semua perusahaan Jepang memelihara budaya senioritas, akibatnya hampir tidak bisa ditemukan senior manager dalam usia 30-an tahun. Istilah Rising Star dan Young Creative Guy adalah keanehan. Promosi di hampir semua perusahaan Jepang menggunakan metode urutan berdasarkan umur yang lebih tua. Pada perusahaan Jepang loyalitas pasti akan sampai pada tahap pensiun, dan apa artinya itu bagi inovasi? Budaya loyalitas permanen membuat inovasi terhenti.

3. Old nation error, factor ini berkaitan dengan factor pertama dan kedua juga dengan aspek demografi. Jepang adalah negeri yang menua, artinya lebih dari setengah penduduk Jepang berusia diatas 50 tahun. Implikasinya, mayoritas senior manager di beragam perusahaan Jepang masuk dalam katagori itu. Kategori karyawan yang sudah berumur lanjut, disini hukum alam berlaku, karyawan yang sudah tua dan bertahun-tahun bekerja pada lingkungan yang sama biasanya kurang peka dengan perubahan yang berlangsung cepat.

Dari kasus tersebut diatas bias dilihat bahwa inovasi yang merupakan bagian dari intellectual capital sangat penting bagi suatu perusahaan, apalagi untuk perusahaan elektronik, inovasi adalah kunci dari segalanya.

\section{SIMPULAN}

Intellectual capital adalah salah satu penentu keberhasilan perusahaan, perusahaan akan mampu memenangkan persaingan atau memperoleh keunggulan bersaing (competitive 
advantage) melalui inovasi yang merupakan bagian dari intellectual capital, baik itu inovasi produk maupun innovasi teknologi, sehingga mampu menghasilkan produk dan jasa dengan kualitas terbaik dan kecepatan dalam proses produksi guna memenuhi kebutuhan pasar dan tidak didahului oleh perusahaan lain. Keunggulan produk yang diperoleh dari inovasi akan memberikan profitabilitas bagi perusahaan, hal ini juga didukung oleh beberapa penelitian yang pernah dilakukan sebelumnya yang menyatakan intellectual capital berpengaruh signifikan dan memiliki arah pengaruh positif terhadap profitabilitas.

\section{DAFTAR PUSTAKA}

Indra Lila Kusuma, 2010, Pengaruh Karakteristik Perusahaan Terhadap Pengungkapan Informasi Intellectual Capital dan Implikasinya Terhadap Reaksi Investor di Indonesia, Jurnal Infestasi, Universitas Trunojoyo.

Martha Kartika \& Saarce Elsye Hatane, 2013, Pengaruh Intellectual Capital pada Profitabilitas Perusahaan Perbankan yang Terdaftar di Bursa Efek Indonesia tahun 2007-2011, Jurnal Akuntansi Bisnis

Organization for Economic Co- Operatin and Development (OECD). 1999. International Symposium on Measuring and Reporting Intellectual Capital: Experiences,
Issues and Prospects.Amsterdam, June .

Stewart, TA. 2002. The Wealth of Knowledge: Intellectual Capital and the Twenty First Century Organization. Great Britain: Nicholas Brealey Publishing.

Stewart, TA. 2002. The Wealth of Knowledge: Intellectual Capital and the Twenty First Century Organization. Great Britain: Nicholas Brealey Publishing.

Sveiby, Karl-Erik. 2001. A Knowledge-Based Theory of The Firm to Guide in Strategy Formulation. Journal of Intellectual Capital: Vol 2.

Santoso, E.C \& Setiawan R (n.d), 2008, Modal intellectual dan dampaknya bagi keberhasilan organisasi, jurnal manajemen, fakultas ekonomi, Universitas Kristen maranatha, Bandung

The International Federation of Accountans. 1998. Measurement and Management of Intellectual Capital. http:/www.ifac.org/.

http://www.bisnis.com

http://www.studentjournal.petra.ac.id 